Urszula Sokólska

DOI: 10.33896/PorJ.2020.6.4

(Uniwersytet w Białymstoku, e-mail: u.sokolska@uwb.edu.p1

ORCID: 0000-0002-3945-1138

\title{
JĘZYK JAKO PRZEDMIOT REFLEKSJI W UJĘCIU ARTYSTÓW PIÓRA DWUDZIESTOLECIA MIĘDZYWOJENNEGO
}

Euforii związanej $z$ odzyskaniem przez Polskę niepodległości po 123 latach niewoli towarzyszą różnorakie działania mające na celu podniesienie kondycji i statusu odrodzonego państwa. A że przełom historyczno-społeczny pociaga za soba przełom w szeroko pojętej kulturze, ważnym elementem owych poczynań staje się język. Stanowi on - co bardzo istotne - przedmiot szczególnej troski władz państwowych, które sa głęboko zainteresowane zarówno społecznym funkcjonowaniem polszczyzny, jak i wszelkimi czynnikami decydującymi o przeobrażeniach systemowych języka. ${ }^{1}$ Potrzebą chwili okazuja się tak ważne cele jak choćby wprowadzanie (przywracanie) opartych na rodzimych wzorcach nazw własnych czy kształtowanie kompetencji komunikacyjnych użytkowników polszczyzny w nowych warunkach. Wiązało się to - między innymi $-z$ polityką edukacyjna, $z$ upowszechnieniem szkolnictwa na poziomie podstawowym, a w konsekwencji zmniejszaniem analfabetyzmu. Dużą wage przywiazywano do zapewnienia odpowiedniego miejsca nauczaniu języka polskiego w programach szkolnych, starano się tworzyć sprzyjajace warunki funkcjonowania organizacjom, stowarzyszeniom, instytucjom działającym na rzecz języka, wspierano inicjatywy zmierzające

1 Rzad wspierał między innymi powołanie Polskiej Akademii Literatury, do której zadań należało wypowiadanie opinii w sprawach dotyczących języka, literatury i kultury polskiej. W działania te szczególnie aktywnie włączył się S. Żeromski i już w 1918 roku ogłosił Projekt Polskiej Akademii Literatury. Pisarz, zwracając uwagę choćby na zalew germanizmów czy niedbałość w posługiwaniu się polszczyzną, podkreślał konieczność dbania o „czystość i piękność języka”, wyznaczał drogi realizacji „misji językowej” z udziałem świadomych użytkowników języka i postulował: „W tej sprawie nie wystarcza doraźne skarcenie przez purystę językoznawcę, lecz konieczna jest stała i pilna praca około języka narodowego w mowie, piśmie i tworzywie, przedsięwzięta przez samych ludzi pióra" [Żeromski 1963 76-77]. PAL została ostatecznie powołana dopiero w $1933 \mathrm{r}$. i istniała do 1939 r. Jednak roli, jaką chciał jej przypisać S. Żeromski w dziedzinie języka, nigdy nie osiagnęła. 
do integracji i kodyfikacji polszczyzny, choćby na poziomie ortografii czy wymowy [por. Dubisz 2012].

Niemała rolę w kształtowaniu wzorców ówczesnej polszczyzny odgrywają również artyści słowa, żywo reagujący na nowa sytuację polityczno-społeczno-kulturalna. Poeci i pisarze biora bezpośredni udział w dyskusji nad nowa sytuacją państwa i uczestniczą w budowie nowej koncepcji szeroko pojętej kultury. W wyrażanych wprost rozważaniach nad kształtem polszczyzny twórcom idzie głównie o zwrócenie uwagi na to, że zmieniona porewolucyjnie i powojennie cywilizacja w istotny sposób wpływa na wizję sztuki, wizję języka, że modeluje nową tematykę literacka oraz wprowadza adekwatne do nowej rzeczywistości sposoby artystycznego przekazu, wcześniej często nieznane lub nie w pełni wykorzystywane. Język - zdaniem artystów - powinien dostosowywać się do zastanej rzeczywistości, a w miarę potrzeby zmieniać swoją strukturę, przede wszystkim zaś reagować na zmieniająca się pod wpływem bodźców zewnętrznych wrażliwość emocjonalno-intelektualną użytkowników polszczyzny. ${ }^{2}$ Wypowiedzi te stosunkowo często bezpośrednio nawiazuja do programów „Skamandra”, awangardy krakowskiej czy futurystów, choć trudno byłoby tu mówić o jakimś jednolitym kanonie języka literackiego, a zatem również i języka ogólnonarodowego. W tej wielowątkowej, urozmaiconej pod względem formalno-emocjonalnym koncepcji dają się - mimo wszystko - wyodrębnić pewne zespoły tendencji, stanowiące oryginalny wkład twórców 20-lecia w dzieje polszczyzny. Obserwujemy $z$ jednej strony umiarkowany tradycjonalizm, dbałość o klasyczność struktury wypowiedzi, $z$ drugiej zaś otwarcie mowy - w tym również mowy poetyckiej - na wszelkie odmiany uwarunkowanej społecznie, kulturowo i środowiskowo praktyki językowej; wreszcie propagowanie autonomicznej i nowatorskiej swoistości form komunikacji artystycznej. Istotna rolę odgrywa eksperymentowanie słowem, quasi-archaizowanie, quasi-etymologizowanie, iluzoryczne naśladowanie języków obcych, a w konsekwencji odnowienie artystycznych form wypowiedzi i odrzucenie wytartych frazeologizmów, efekciarstwa i koncepcji natchnionego wieszcza romantycznego, jednak bez naruszenia istotnych gramatyczno-leksykalnych właściwości i norm języka ogólnonarodowego. ${ }^{3}$ Drugi nurt reprezentowali między innymi futuryści i przedstawiciele awangardy krakowskiej, którzy stawiali na prowokację i wolność we wszelkich jej przejawach, eksponowali w swoich utworach ekstrawagancję i oryginalność:

2 Należy podkreślić, że wielu twórców tego okresu traktowało język nie tylko jako tworzywo literackie, ale też przedmiot refleksji quasi-naukowej. Artyści starali się wchodzić przynajmniej częściowo w rolę językoznawców i podejmowali trud zgłębiania tajników systemu językowego, czasami nawet formułowali wnioski o charakterze teoretycznym.

3 Szerzej na ten temat: Sokólska 2017, 249-276; też: Sokólska 2018; Sokólska 2019. 
Sztuka dotychczasowa była powtarzaniem własnymi słowami tego, co mówiła sztuka epok poprzednich. Ale zamiast powtarzać, możemy mówić za siebie; zamiast naśladować, możemy tworzy $\dot{c}^{4}$ [Peiper 1979, 34],

a nawet odrzucali jakakkolwiek tradycję, w tym obowiazujące zasady ortograficzne, interpunkcyjne, gramatyczne i morfologiczne, ${ }^{5} \mathrm{np}$.:

Artysta, ktury nie twoży żeczy nowyh i ńebywałyh, a pszeżuwa jedyńe to, co było pszed ńim zrobione, po paręset razy - ne jest artystą i powińen za używańe tego tytułu odpowiadać sadowńe, (...) Wzywamy społeczeństwo do zorganizowanego bojkotu podobnyh jednostek [Jasieński 1921].

Twórcy piszą o takim gospodarowaniu słowem / / mowa / językiem, by były one nakierowane na artystyczne i emocjonalne cele każdej wypowiedzi, nie tylko artystycznej, co w konsekwencji ma prowadzić do wyobrażeniowego, namacalnego odbierania aktu komunikacyjnego. $Z$ kolei sama polszczyzna w ujęciu ludzi pióra przybiera różnoraki kształt i w zależności od porządku chronologicznego staje się bądź to przedmiotem admiracji:

Język to dzieje duszy narodu od zamierzchłych pradawnych czasów, (...), po cudowną mowę Mickiewicza, po wspaniała muzykę oktaw Słowackiego, po płomienna prozę autora Irydiona. (...) Język jako zwierciadło oddał w sobie ducha narodu, uchwycił go i nadał mu kształt. (...) Tam ma swoje źródło nieśmiertelność narodu [Dębicki 1925, 33],

bądź to obiektem uzasadnionej krytyki:

Ścierką dziś śmierdzi polska mowa śliczna / I zwie się teraz krótko: polemiczna / (...) / Słowa dziś polskie bija po pysku! / W błocie się grząskim polska mowa tarza, / A gdy spotkają się dwa w wielkim ścisku, / To jedno drugie trądem wnet zaraża [Makuszyński 1929,183].

Nie brakuje tu sformułowań niezwykle ważnych i celnych, często noszaccych znamiona naukowe, ale jest też wiele sądów emocjonalno-wartościujących, przyjmujących strukturę nieskonwencjonalizowanych metafor.

\section{W POSZUKIWANIU NOWEGO JEZZYKA, W POSZUKIWANIU NOWEGO SEOWA}

Zgodnie $z$ przyjęta przez Juliana Przybosia wizja procesu twórczego jako „pracy w materiale językowym” właśnie sztuka słowa sprawia, że możemy poznawać świat za pomoca złożonych operacji językowych. Nie

${ }^{4}$ Ten sposób wyodrębnienia tekstu przejmuje za wydawca dzieł T. Peipera.

5 Problem podnosiłam w tekstach: Sokólska 2013; Sokólska 2015; Sokólska 2018. 
bez przyczyny zatem wypowiedzi quasi-językoznawcze oraz manifesty programowe ówczesnych twórców przybieraja formę wypowiedzi specjalistycznej, zbliżającej się pod względem terminologicznym do fachowego tekstu naukowego. Jako przykład moga posłużyć poniższe fragmenty treścią i strukturą definicyjna imitujące wypowiedzi stricte językoznawcze. Bez trudu można bowiem zauważyć, że użyte przez pisarzy i poetów sformułowania typu: organizować język, język jako społeczne narzędzie, prawo rozwoju języka, usprawnienie języka, ekspresja językowa, ekonomia mowy, ekonomizm językowy, operacje językowe, martwy język, język surowy, język szesnastowieczny czy wypowiedzenia o charakterze oznajmień (język służy...), odnaleźć można w wielu pracach podnoszacych problemy lingwistyczne, np.:

Sztuka (...) pozwala poznawać świat poprzez złożone operacje językowe [Peiper 1925]; Organizując język, (...) przysługuje się poezja społeczeństwu jako czułe narzędzie myślenia. (...) Usprawnienie języka, tego najbardziej społecznego narzędzia, oto obiektywnie społeczna wartość poezji. Nowoczesna poezja to (...) laboratorium coraz sprawniejszych sposobów ekspresji językowej [Przyboś 1927]; Ekonomia mowy jest jednym $z$ praw rozwoju języka. A ekonomizm językowy - jednym $z$ haseł nowej literatury [Peiper 1974, 100]; Język służy celom biotycznym, naukowym i artystycznym [Bocheński 1936, 121]; Gdzie jest granica dobrego i złego języka? Język raz ustalony stanie się martwy [Boy-Żeleński 2001, 147]; nasz język szesnastowieczny był bardzo surowy, bardzo skromny [Boy-Żeleński 2001, 232].

Język - nawet w ujęciu metaforycznym - bywa traktowany jako system, którym rządzą określone prawidła i normy, $z$ czasem ulegajace procesom ewolucyjnym, np.:

Żadnej regule gramatycznej nie można przyznać prawa wetowania wobec potrzeb myśli poetyckiej. Uzasadnione sa nawet pewne stałe reformy syntaktyczne. Gramatyka nie jest przepisem, lecz spisem. Uporządkowanym spisem. Nie daje norm, lecz konstatuje fakta. (...) W składniach poszczególnych języków zajdzie w przyszłości wiele zmian, lecz będa to zmiany o charakterze reform, a nie destrukcji [Peiper 1979, 115].

Lingwistyczne refleksje twórców literatury międzywojennej łączą się z pojmowaniem natury i języka jako swoistej jedności, w której wizja procesu twórczego, nazywana też metaforycznie „praca w materiale językowym", wiąże się z prawem poetyckiego mówienia o sprawach świata w sposób zindywidualizowany i niepowtarzalny. Dlatego też w analizowanych tekstach dotyczacych kondycji i kształtu polszczyzny odnajdujemy to, co zwykło się przypisywać konstrukcjom metaforycznym: hiperboliczność ujęcia języka, konkretność przedstawieniowa obok abstrakcji i konceptualizmu, dynamiczność obok statyczności. Właściwe tego typu deliberacjom sa wielowarstwowe - pozytywnie nacechowane - konceptualizacje dotyczace estetycznego i wyobrażeniowo-emotywnego efektu wypowiedzi: 
Język, to cudowne narzędzie przeznaczone do porozumiewania się ludzi między sobą, do oddawania najdelikatniejszych uczuć i najszczytniejszych myśli, ma swój dźwięk i swoją barwę [Dębicki 1925, 32]; Język to organ, który chwyta życie materii z całą jego falująca zmiennością [Przyboś 1927]; Ciagła inwencja tego języka, niespodzianki napotykane po drodze podtrzymują żywość wrażeń i pozwalaja przebyć tę „podróż” do końca [Boy-Żeleński 2001, 145]; Jeżelim, Stwórco, posiadł Słowo, dar twój świetny, / Spraw, by mi serce biło gniewem oceanów, / Bym, jak dawni poeci prosty i szlachetny, / Wichura krwi uderzał w możnych i tyranów. / (...) / Lecz słowom mego gniewu daj błysk ostrej stali, / Brawurę i fantazję, rym celny i cienki, / Aby ci, w których palnę, prosto $\mathrm{w}$ łeb dostali / Kula $z$ sześciostrzałowej piosenki! [J. Tuwim, tom Słowa we krwi; Prośba o piosenke]; Słowo jest winem i miodem, / Słowo jest mięsem i chlebem, /Słowami oczy wiodę / (...) / Nie mam żadnego zajęcia:/ Jestem tylko łowca słów. / Czujny i zasłuchany / Wyszedłem w świat na łów [Tuwim, tom Słopiewnie; Słowo i ciało].

Koncepcję ówczesnego języka ogólnego literaci ściśle wiązali z językiem poezji, który według nich był szczególnym subkodem nadbudowanym na języku naturalnym. Jak twierdził J. Przyboś, „poezja to język w języku", stąd też celem poezji powinno być odkrywanie nieznanych dotychczas możliwości języka. Jednym ze środków pozwalających na dotarcie do istoty języka jest metafora, bardzo często wykorzystująca zjawiska polisemii i homonimii, oparta na trudno definiowalnych znaczeniach i wielorakich konotacjach; zróżnicowana w zależności od tego, czy mamy do czynienia $z$ prozatorska czy poetycką organizacją tekstu. W tym właśnie T. Peiper widzi szerszy, ogólnospołeczny, komunikacyjny aspekt języka artystycznego, zdolnego do stwarzania ekwiwalentów słownych rzeczy i uczuć. Dlatego też formułuje postulat różnicowania wypowiedzi pod względem formalnym, w zależności od potrzeb komunikacyjnych: „Proza nazywa; poezja pseudonimuje” [Peiper 1979, 145].

W tym czasie daje o sobie znać krytycyzm wobec zastanych form językowych, koncentrujący się na ośmieszaniu i kompromitowaniu wyspecjalizowanych poetycko struktur leksykalno-semantycznych, typowych dla mowy artystycznej epitetów, peryfraz i przenośni. ${ }^{6}$ Również język ogólny okazuje się nazbyt ubogi, by oddać zmieniająca się rzeczywistość. $\mathrm{Z}$ tego powodu Bruno Jasieński traktuje go jako bezduszne tworzywo,

${ }^{6}$ Do tego typu deklaracji nawiązują utwory J. Tuwima, awangardy krakowskiej, teksty futurystów czy wreszcie prześmiewcze wiersze K.I. Gałczyńskiego oparte na zderzaniu tzw. poetyzmów $z$ wyrazami pospolitymi, rubasznymi, wręcz wulgarnymi. Poetyzm tracił w ten sposób swoja poznawczo-ekspresywna funkcję, w pewnym sensie demokratyzował się, a nawet nabierał cech śmieszności i stawał się obiektem zasługującym na lekceważenie. I o ile jednak stosunek wobec poetyzmów wśród ówczesnych twórców i teoretyków literatury wydaje się podobny, o tyle już w ocenie wyrazów wulgarnych i obscenicznych artyści wyraźnie różnią się. T. Peiper pisze tak: „A jednak wulgaryzm to wstecznictwo, to zwrot wstecz zamiast zwrotu naprzód. Sprawia on, że człowiek naszego czasu bierze w siebie na chwilę człowieka prymitywnego i mówi jego sposobami. Znowu prymityw staje się wzorem" [Peiper 1979, 76]. 
niezdolne do wyrażania głębokich emocji i wszelkich intelektualnych doznań:

Zmęczył mnie język jak twardy zlepek. / Jestem jak człowiek, co lampy przerósł. / Na skrzyżowaniu dwóch wrogich epok / stoję, cynicznie gryząc papieros [B. Jasieński, Zmęczył mnie język].

Niewystarczalność, ułomność zestandaryzowanego języka sprawia, że $\mathrm{w}$ tekstach artystycznych międzywojnia rysuje się koncepcja poety robotnika, przewodnika „pracowitej gromady”, łowcy i sprawcy wyrazów, „alchemika słowa”, „słowiarza” zachowującego się niczym obdarzony inwencją rzemieślnik, który zdolny jest do przekształcania materii słownej i budowania niepowtarzalnej wyobraźni językowej. Ów pragmatyczny, materialno-rzemieślniczy charakter pracy z językiem sprzyja odkrywaniu znaczeń nowych i utajonych, wydobywanych kontekstowo dzięki umiejętnie rozlokowanym zestrojom leksykalnym:

Trzeba mowę, narzędzie naostrzyć [J. Przyboś, Oburącz];

Twardym słowem pracuję. Usilną uprawa męstwa / zorganizuję sumienia, rozpędzę wyścig pierwszeństwa, / przepłynę prądem przez serca, iskry energii wyzwolę, / zmuszę was do zawodów o rekord tworzącej woli [J. Przyboś, Śruby].

Poeta, zgodnie $z$ koncepcja T. Peipera oraz wczesnego J. Przybosia, miał być blisko zwiąany ze światem cywilizacji, miasta, społeczeństwa. U podstaw tych nowatorskich teorii leżał pogląd, że doznania emocjonalno-estetyczne zwiazane $z$ odbiorem tekstu artystycznego zależą nie od jego rozumienia, ale od językowej magii wywołanej kreacyjnymi działaniami twórcy, często odległymi od norm naturalnego języka komunikacyjnego:

Że wychodzą $z$ niej twory nie zawsze dla wszystkich zrozumiałe, to trudno. Ktoś atakował niezrozumiałość nowej poezji przypomnieniem, że język jest społecznym narzędziem porozumiewania się. (...) Język jest narzędziem społecznego porozumiewania się owszem, lecz może doskonalenie tego narzędzia wymaga, aby ludzie czasem nie zrozumieli się; choćby przez chwilę; przez jedno pokolenie. Tworzenia hamować to nie może. Stróżowie narzędzia społecznego! Ileż to narzędzi społecznych straciliśmy, nie stworzywszy ich! [Peiper 1979, 78-79].

Według bardziej wyważonych teorii poeta powinien jednak poszukiwać języka zapewniającego skuteczne porozumienie między nadawcą a odbiorca każdego tekstu, powinien odkrywać i uwalniać słowa, które byłyby wierne nazywanej rzeczy, pozbawione dekoracyjności i manieryzmu, ale za to zwrócone ku codzienności, językowi potocznemu i gwarowym korzeniom:

Naturalizm odbarwił kolor języka. Są wyrazy, zwroty, z których zrobiły się istne trupy. Jak odnowić pewne słowa wyciśnięte do ostatka, jeżeli nie wracając do źródła języka, który, ostatecznie, zawsze jest gwarą? Gwara połaczona z narzeczem ludowym, zawsze dramatycznym i przejmującym. Czy pan myśli, że oficjalny język literacki też nie jest gwarą? [Boy-Żeleński 2001, 147]. 
Uwalnianie słów objawiało się tym, że twórcy na użytek swojej poezji wymyślali nieistniejace dotąd wyrazy. Owo neologizowanie („leksykalne zbuntowanie") przebiegało w dwóch kierunkach. $Z$ jednej strony polegało na tworzeniu wyrazów zbudowanych ze znanych morfemów i według wzorców przyjętych w polszczyźnie (np. Tuwimowe: grekowisko, gryzmoła, literacina, podlasina, podsłowie, szeleścina, zieliszcze, zielszczyzna, ziołowied, żmudzisko), z drugiej zaś - na demontowaniu całostki wyrazowej, rozbijaniu jej na segmenty, które następnie były włączane do wypowiedzi jako pełnoprawne składniki leksykalne (np. u B. Jasieńskiego: „na rzece rzec ce na cerze mrze/ (...) / o trafy tarów żyrafy raf / ren cerę chore o ręce / na stawie ta wie na pawie staw / o trące tren teren ce; Na rzece).

Odwieczny problem artysty poszukującego odpowiedniej formy do przekazania skomplikowanych treści ujawnia się w wypowiedziach podnoszących problem metafory językowej, która pozwala na uwikłanie słowa w konteksty obce polszczyźnie codziennej. Istotą takich połączeń staje się to, że pojedyncze słowa wyizolowane ze stałych, słownikowych znaczeń poddaja się twórczej myśli i wyrażaja wszystko, co wydaje się niewyrażalne i niepoznawalne. Słusznie też twórcy międzywojnia uwydatniają znana już od starożytności tezę, iż łączliwość wyrazów w metaforze ma charakter nieograniczony:

Nie ma takich słów, które by nie miały jakiejś sytuacji mogącej uzasadnić ich metaforyczne połączenie [Peiper 1979, 156],

a sama konstrukcja uznawana jest za czynnik sprzyjajacy eliptyczności, ekonomii i większej precyzji wypowiedzi. Jest też zaprzeczeniem wielo- i pustosłowia, sposobem na budowanie nieoczekiwanych konotacji i eksponowanie dodatkowych, niedefinicyjnych treści kojarzonych przez użytkowników danego języka $z$ opisywana sytuacją:

\footnotetext{
Słowo metaforyczne wystarczy często do wypowiedzenia myśli, która w mowie prozaicznej wymagałaby długiego gadania (...). Otóż w tym długim gadaniu ginie całość myśli. To, co w umyśle naszym pojawia się w jednej chwili, to w mowie niemetaforycznej rozkłada się na opisy, określenia, ustosunkowywania, sytuacje. Jest za wiele słów, abyśmy jeszcze mogli odczuwać całość. Natomiast metaforyzacja daje te rzeczy splecione, nie, więcej, zrosłe, i zrosty te tworzy szybko. Jest więc bliższa naszym procesom myślowym. Widzimy rzeczy jako całości, pamiętamy zdarzenia jako całości, odczuwamy przeżycia jako całości, a mowa zwyczajna rozkłada je długo na kawały [Peiper 1979, 160];

metafora to samowolne spokrewnienie pojęć; (...) którym w świecie realnym nic nie odpowiada [Peiper 1925, 68].
}

Inaczej mówiąc, metafora - choć nie notuje i nie opisuje spraw takimi, jakimi one sa - to scala i kategoryzuje trudno uchwytne procesy myślowe, zaspokaja trudne do wyrażenia potrzeby intelektualne użytkowników języka. Podnosi też walor emocjonalny i estetyczny wypowiedzi. 
W sprawie ówczesnej leksyki bardzo zdecydowanie, wręcz autorytatywnie wypowiadał się również S. Żeromski, który zajmował się problemami języka ojczystego nie tylko ze stanowiska artystycznego, ale też ogólnokomunikacyjnego, organizacyjnego i dydaktycznego. W swoim dziele Snobizm i postęp ${ }^{7}$ przedstawił m.in. własna koncepcję kultury języka, dał krótki rys dziejów języka literackiego, wskazał na konieczność badania gwar ludowych, póki one jeszcze w swej odrębności istnieją; postulował też sięganie do zasobów językowych czasów minionych. Według S. Żeromskiego ze słownictwa staropolskiego i ludowego można by zaczerpnąc wiele odpowiedników terminów specjalistycznych, „niepotrzebnie każących polszczyznę barbaryzmów". ${ }^{8}$ Według pisarza nazwy te nazywaja

dziesięćkroć od naszego obszerniejszy zasób rzeczy, pojęć i czynności, ruchów i odczuwań, które człowiek naszego rodu przez tyle wieków w walce $z$ dzika przyrodą i w trudzie niezmiernym utworzył.

Dokonując długich wywodów etymologicznych, niezbyt trafnie dowodził sensowności zastapienia np. terminów izba poselska i izba sejmowa, minister, ambasador, gabinet przez odpowiedniki staropolskie bądź gwarowe:

Co więcej - gabinet ministrów jest terminem bardzo niewłaściwym, gdyż wyraz gabinet ma rozmaite znaczenie, nie wyłączając jednego o niedyspozycyjnym charakterze. Tymczasem istnieje prasłowiański termin trzem, oznaczajacy pokoje górne, tajemne, niedostępne. Nie powinno by się mówić gabinet ministrów, lecz trzem pełnomocników, bo i słowo minister jest wyświechtanym liczmanem europejskim, podczas kiedy pełnomocnik jest naszym własnym i przepysznie rzecz malującym określeniem tego urzędu. Mówi się nawet o ambasadorze, czyli pośle: minister pełnomocny. Tak tedy wysokie urzędy nasze mogłyby otrzymać polskie nazwy: 1) naczelnik, 2) pelnomocnik, 3) trzem pełnomocników, 4) samborza poselska.

Za czasów Stanisława Augusta mówiono jeszcze sesya, a wkrótce potem sesja uschła i weszło w użycie - posiedzenie. Mogłoby to samo być teraz z samborza, trzemem i pet-

7 Zainteresowania językowe S. Żeromskiego oparte były na rzetelnym studiowaniu dawnych tekstów i oczytaniu w literaturze lingwistycznej. Jego Snobizm i postęp poświęcony w dużej części sprawom językowym i językoznawczym został wysoko oceniony przez najwybitniejszych lingwistów tego czasu. Jan Rozwadowski pisał: „[książka; dop. U.S.] była miła i prawdziwa niespodzianką dla ludzi pracujących naukowo nad językiem polskim" [Rozwadowski 1923, 87]. Pisarz uwypuklił tu m.in. gwarowe korzenie polskiego języka literackiego oraz skomentował wpływ zapożyczeń na kształtowanie się leksyki w polszczyźnie; zwrócił ponadto uwage na rozwój norm ortograficznych oraz progresywny charakter pozostałych podsystemów językowych. Za „idealnie polska, to znaczy najbardziej wolna od wpływów zewnętrznych", uznawał S. Żeromski bliska swemu sercu gwarę terenów świętokrzyskich.

8 Frapowało go słownictwo dawne i regionalne, $z$ całym anturażem i możliwie szeroka sferą semantyczno-etymologiczną. W tym właśnie widział drogę wzbogacania leksyki współczesnego mu języka ogólnego. 
nomocnikiem. Mogłoby, lecz stoi na przeszkodzie najtkliwszy ze snobizmów, snobizm urzędniczy, któżby się zdołał wyrzec tytułu pan minister i zamienić to na ordynarne określenie petnomocnik?

[Żeromski 1923, https://literat.ug.edu.pl/snobizm/0009.htm].

Zacytowany wyżej przykładowy komentarz dotyczący losów wyrazów w polszczyźnie jest na pewno potwierdzeniem rzetelnej wiedzy pisarza na temat historii języka, świadczy też o znajomości dzieł najwybitniejszych językoznawców tamtego czasu. Nie można jednak zgodzić się ze wszystkimi, chwilami skrajnie purystycznymi uwagami Żeromskiego poświęconymi choćby zapożyczeniom, $z$ których większość przetrwała wieki, aż do dzisiaj. Wystarczy przyjrzeć się na przykład wielu zadomowionym w polszczyźnie latynizmom, $z$ taka gwałtownościa piętnowanym przez pisarza:

Tłum szlachecki łatał mowę pospolitą wyślizganymi komunałami łacińskimi, oraz spolszczył niezliczoną ilość wyrazów. Łacina zubożyła język narodowy, skazując go na bezczynność, bierność i zdrewniałe trwanie. Tu snobizm polski włóczenia się wydeptanymi szlaki, wyjeżdżonym łacińskim łożyskiem rozpanoszył się niebywale. Począwszy od wyrazów szkolnych: kałamarz, atrament, temperować pióro, bibuła, arkusz, okulary; kościelnych: parafia, dziekan, biskup, pleban, ołtarz, msza, nieszpory; poprzez nieprzebrane mnóstwo wszelakich afektów, despektów, suplik i rewerencji, akomodowania się, responsów, amorów, impetów, ans, submisji i wszelkich, jakie tylko w świecie polskim być mogły, interesów [Żeromski 1923, https://literat.ug.edu.pl/ snobizm/0006.htm]

Nie da się jednak tych nie w pełni właściwych ocen S. Żeromskiego uznać za zjawisko wyjatkowe w polskiej kulturze i myśli językoznawczej oraz quasi-językoznawczej. Zmiany słownikowe od zawsze bowiem budziły najwięcej kontrowersji i emocji, ale najczęściej też - spośród wszystkich zmian językowych - okazywały się nieprzewidywalne. Stąd i osądy w sprawie tak szczegółowych zagadnień jak zjawiska leksykalne okazywały się w przeszłości po wielokroć nietrafne. Nie można przy tym odmówić słuszności poglądom pisarza wobec wielu przeobrażeń językowych o charakterze systemowym, choćby jego ocenom dotyczącym ortografii czy składni.

\section{SPÓR O SKLADNIE}

J. Przyboś podkreśla, że najważniejszą oprawa każdej wypowiedzi jest składnia. Bez niej mielibyśmy do czynienia jedynie $z$ inwentarzem świata, nie zaś $z$ oddawaniem życia tego świata. Jalu Kurek, inny przedstawiciel awangardy krakowskiej, wyznaje podobną zasadę:

Istota poezji tkwi nie słowach, lecz w wiazaniach słów. Słowo jest łobuzem, a zdanie jest już czymś odpowiedzialnym [Kurek 1933]. 
Wielką wagę do zagadnień syntaktycznych przywiązuje również T. Peiper, uznający składnię za „aparat notujący zwiąki zachodzące między zjawiskami i językowe odbicie tych związków". Twórca poddaje krytyce poetykę F.T. Marinettiego, a zrywanie więzi składniowych określa jako „niecelowe i przeciwcelowe”. W obrębie składni dopuszcza jedynie drobne, intencyjnie i twórczo uzasadnione odstępstwa:

Bez niej [składni - dop. U.S.] nie ma zwiazku zjawisk. Bez niej rzeczywistość rozpada się na przedmioty i zdarzenia, dla których jedynym orzeczeniem może być tylko pojęcie "jest” lub „sa”. (...) O żadnych odkryciach mowy być nie może, bo odkrywanie jest to tworzenie nowych zwiazków. Tak więc postulat burzenia składni M. mija się ze swym celem [Peiper 1979, 114];

Tylko zdanie może być terenem zdobyczy literackich. (...). Oczywiście w obrębie zdania dopuszczalne sa wszystkie swobody, jakich wymaga intencja poety [Peiper 1979, 115].

Postawa taka sprzeczna była $z$ tezami futurystów, którzy zdanie uznawali za antypoezyjnego dziwolaga. Wzorem teoretyków włoskich głosili oni całkowita autonomię poszczególnych słów, konieczność oderwania ich od tradycyjnej i logicznej składni. Za najważniejsze części mowy uważali rzeczownik oraz czasownik w postaci bezokolicznikowej (a więc całkowicie uniezależniony od wykonawcy czynności), co zgodnie $z$ wyznawana przez nich ideologia miało „ukazywać nieskończona kinetykę rzeczywistości i składniową niezależność". Z kolei niekorzystnie na poetyckie obrazowanie - ich zdaniem - wpływały przymiotniki i przysłówki, spowalniajace dynamizm przedstawianych rzeczy i obrazów. Kwestionowali potrzebę mówienia o podmiocie i orzeczeniu, uznając te pojęcia za pęta ograniczające artystyczną wolność poety:

Poezja jest taką kompozycją słuw, aby ńe zabijając tej drugiej konkretnej duszy słowa wydobyć $z$ ńego maximum rezonansu. (...) Pszekreślamy zdańe jako antypoezyjny dźiwolag. Zdane jest kompozycją pszypadkowa, spojona jedyńe słabym klejem drobnomieszczańskiej logiki. Na jego miejsce - skondensowane, ostre i konsekwentne kompozycje słuw, ńe krępowanyh żadnymi prawidłami składni logiki czy gramatycznośći, jedyńe twarda wewnętszna końecznościa, ktura po tońe A domaga się tonu $\mathrm{C}$, po tońe $\mathrm{C}$ tonu $\mathrm{F}$ it.d. [B. Jasieński, Manifest $w$ sprawie poezji futurystycznej].

\section{SPORY O ORTOGRAFIE}

Ważnym elementem odnowy języka miało być odrzucenie istniejacych zasad ortograficznych i gramatycznych. Swój program B. Jasieński, T. Czyżewski, S. Młodożeniec, A. Wat i inni ogłosili na łamach czasopism: „JEDNODŃUWKA FUTURYSTUW mańifesty futuryzmu polskiego wydańe nadzwyczajne na cała Żeczpospolita Polska” oraz Nuż $w$ bżuhu. Jednodńuwka futurystuw: 


\begin{abstract}
Absurdem jest dla wyrażeńa jednego i tego samego dźwięku używańe 2 rużnyh znakuw (liter). Dlatego skreślamy raz na zawsze $z$ alfabetu polskiego jako zbyteczne litery ó i rz, pońeważ w wymawiańu ńe rużńą see ńiczem od liter $\mathbf{u}$ i $\dot{\mathbf{z}}$ lub sz i bez szkody dadzą śę pszez ńe zastapić. (...) połączeńe liter $\mathbf{c h} z$ alfabetu polskiego wykreślamy. (...) Zadańem tej reformy elementarnej jest jedyńe oczyszczeńe pisowni polskiej z całego balastu znakuw zbędnyh, a tem samem szkodliwyh [Jasieński 1921b].
\end{abstract}

Programowi futurystów sprzeciwiała się większość twórców i myślicieli tego okresu. K. Irzykowski w artykule Futuryzm a szachy, zamieszczonym w 1921 roku pierwotnie na łamach czasopisma „Ponowa”, a później przedrukowanym w książce Słoń wśród porcelany, pisał m.in.:

Mowa jest więzią społeczną: kto ją rozluźnia bez wypowiedzenia, bez zawarcia nowej konwencji, karany jest automatycznie niezrozumieniem [Irzykowski 1934, 96].

W podobnym tonie wypowiadał się S. Żeromski. Program futurystów poczytywał on za zgubne sprzeniewierzenie się tradycji i przekreślenie pięćsetletniej narodowej żmudnej pracy wielu pokoleń w dziedzinie graficznego opanowania języka plemiennego. Twierdził, że ortografia dowolna cofa nas do sposobów utrwalania dźwięków przez pismo, jakiego chwytano się w księgach z początków piśmiennictwa polskiego, gdy skryba nie mogac sobie dać rady $z$ wypisaniem po polsku choćby terminu kara wsteczna, pisał raz stweczna, wszetczna, kiedy indziej wcsztna, wsstczna, wssechna. Zwraca uwage na to, że ortografia polska była w miarę ustabilizowana już między XIV a XVI stuleciem i że już wówczas odróżniano w piśmie $u$ od ó i $\dot{z}$ od $r z$. Na dowód przywołuje traktat Jakuba Parkoszowica $z$ Żórawic De ortographia polonica libellus z 1440 r. i Ortografię Stanisława Zaborowskiego z 1513 roku:

Temuż losowi ulega, gdyż ulegać musi, produkcja literacka, nie licząca się z żadnymi względami, narodowymi, społecznymi, wychowawczymi, a nawet $z$ zasadami gramatyki, logiki i estetyki, jak, na przykład, „Nuż $w$ bżuchu”, albo „Pieśń o głodźe” Brunona Jasieńskiego. (...) Zecerzy muszą ślepiać, składając cudaczne wyrazy, korektor w głowę zachodzi, dlaczego ma poprawiać dni dziwne na dńi dźiwne, pędziły na pendźły, chodnikami na hodńkami i tym podobne. Gdy się widzi, jak na dłoni szkodę pięknych usiłowań artystycznych, podjętych ku nieuświadomionej może, lecz niewatpliwej szkodzie języka polskiego [Żeromski 1923: https://literat.ug.edu.pl/snobizm/0003.htm].

Według pisarza człowiek, który celowo i na przekór tradycji łamie normy ortograficzne, zachowuje się nieodpowiedzialnie, czyni z siebie dziecko lub analfabetę, przede wszystkim zaś „staje na tej samej wyżynie, co pisarz z XV wieku, który, chcąc wyrazić zdanie „przyszwa przyszyta szyciem igły", pisze $z$ łacińska, jak może i umie: przyszpha przyszytha szyczym gybly" [Żeromski 1923: https://literat.ug.edu.pl/ snobizm/0003.htm]. 


\section{CIĄGLOŚĆ JĘZYKOWA CIĄGLOŚCIĄ KULTURY NARODOWEJ}

Korzystając $z$ bogatej - dostępnej już na początku ubiegłego stulecia - literatury językoznawczej, a także najróżniejszych tekstów, począwszy od najstarszych zabytków języka polskiego, poprzez traktaty ortograficzne, gramatyki dawne i mu współczesne, po utwory artystyczne doby staro-, średnio- i nowopolskiej, S. Żeromski dał w Snobizmie i postępie w miarę dokładny rys dziejów polszczyzny. Choć obiektywizm naukowy miesza się tu $z$ subiektywizmem pisarza, to jednak całościowy obraz nie przeszkadza w ukazaniu dynamizmu procesów stricte lingwistycznych i pozalingwistycznych towarzyszących rozwojowi języka. Służy także uświadomieniu ogółowi społecznemu roli, jaka odgrywa język w kształtowaniu tożsamości i świadomości narodowej. Pisarz eksponuje rolę ludzi kultury, z uznaniem mówi o słownikach języka polskiego, o roli wybitnych pisarzy w budowaniu wzorcowej polszczyzny czy wreszcie walce o utrzymanie języka w czasie zaborów. S. Żeromski nie ma watpliwości, że ostateczny kształt języka jest wypadkowa wielowiekowych i wielopłaszczyznowych, uwarunkowanych kulturowo oraz społecznie różnorakich działań, że język bywa sprawcą i biorcą elementów pozalingwistycznych, że gromadzi w sobie niezliczone zjawiska i emblematy przeszłości. Bez tej przeszłości nie ma ani teraźniejszości, ani tym bardziej przyszłości języka i narodu. Inny twórca, pisarz i publicysta wyraża tę myśl S. Żeromskiego w taki oto sposób:

Język zachował nam i zwrócił Pomorze Kaszubskie. Język zachował nam i zwrócił Śląsk Górny. Nie tylko to jednak. Jak wykopaliska, jak stare łzawice i szczattki broni krzemowej, jak naszyjniki wydobywane $z$ cmentarzysk prasłowiańskich sa dokumentami cywilizacji narodu, tak samo sa nimi wyrazy naszego języka [Dębicki 1925, 35].

\section{POSTULATY}

Twórcy znakomicie rozpoznawali potrzeby społeczne niepodległego państwa. Tworząc koncepcje nowoczesnego języka, pośrednio tworzyli też koncepcję edukacji kulturowej, kształtowanej poprzez każde twórcze działanie, poprzez każdy tekst przyjmujący świadomie ukształtowaną formę literacką:

Żeby być rolnikiem - trzeba umieć uprawiać ziemię. Żeby być pisarzem - trzeba umieć pisać po polsku [Peiper 1979, 258];

Rychło zdałem sobie sprawę, że owym c z y m ś, co przykuwa, jest język książki, tak odległy od zwykłych form literackiego stylu. Interesuje sam przez się, działa ożywczo, tonizująco, zaskakuje, niepokoi [Boy-Żeleński 2001, 145];

poezja, doskonaląc język, udoskonala postrzeganie rzeczywistości i wpływa na jej przekształcanie [Peiper 1974, 214]. 
Niemała w tym rola artysty, który - mimo swych intencji - nie zawsze jest w stanie poradzić sobie $z$ trudna materia teoretycznojęzykową. Dlatego S. Żeromski przywołuje w swoich opracowaniach i odezwach wybitnych językoznawców (A. Brücknera, K. Nitscha, J. Baudouina de Courtenay, J. Rozwadowskiego, J. Łosia), którym nie tyle wyznacza cele i kierunki działań, ile raczej prosi o wsparcie, np.:

Wydział językowy [w ramach Akademii Literatury Polskiej; dop. U.S.], wydział doskonałości artystycznego słowa, złożony $z$ przedstawicieli pisarstwa, władających materiałem twórczym w sposób nie tylko nieposzlakowany pod względem gramatycznym i stylistycznym, ale nadto w sposób nie splamiony wpływami zewnętrznymi. Takich pisarzów posiadamy. Instytucja projektowana ośmieliłaby się może zaczepić nawet uczonych językoznawców, tak bardzo zasłużonych, jak np. prof. A. Brückner, który daje nam (...) rozmaite rady i wskazówki co do oczyszczenia mowy z naleciałości obcych [Żeromski 1963, 89].

Uważał S. Żeromski, iż językoznawcy i pisarze powinni ze sobą współpracować, aby zapobiec „ukazywaniu się istnych monstrów, straszydeł przerażających ogromem zbrodni językowych”. Żarliwie upominał się o podjęcie powszechnego wysiłku dla uzdrowienia mowy ojczystej:

Jesteśmy na progu wiedzy o naszym języku narodowym, ale nie przekroczymy tego progu, jeśli szeroki ogół nie uświadomi sobie przy dobrej woli konieczności powzięcia i wykonania pracy powszechnej w tej dziedzinie [Żeromski 1963, 287]

oraz wspieranie pod tym względem lingwistów, których głos nie zawsze jest właściwie wysłuchany w rodzinnym kraju. Wprost mówi o tym w artykule Drożyzna i Zamojszczyzna:

Kto najbardziej nie doznaje opieki, poparcia, uznania, sympatii, zainteresowania, współczucia w tym naszym świecie pełnym „kawałów”, to tacy pracownicy, jak Aleksander Brückner, (...) Kazimierz Nitsch i tylu innych znakomitych a nieznanych. (...) Prace Jana Rozwadowskiego doznały niedawno aplauzu w Sorbonie. A cóż o nich wie wesoła Warszawa? (...) Nie pomoże wołanie ani nawet krzyk: poczynania wymagające pracy zbiorowej nie znajduja wśród nas oddźwięku. Wśród obojętności czytającego ogółu przesuwaja się kapitalne prace Jana Łosia (...) i tylu innych pracowników [Żeromski 1963, 179].

Badajac dzieje polszczyzny, na pewno nie wolno zapominać o czynnikach kształtujących stosunek wybitnych jednostek kulturotwórczych do języka narodowego i narodowej kultury. Nie należy też rezygnować z sygnalizowania elementów budujących i porządkujących świadomość jednostki na tle polskiej grupy etnicznej, nawet jeśli - jak widać to na przykładzie skonstruowanej przez ludzi pióra quasi-lingwistycznej teorii polszczyzny dwudziestolecia międzywojennego - koncepcje te moga być niejednorodne i wewnętrznie sprzeczne. Przecież, mimo wielu różnic, wszystkie te postawy łączy dążność wybitnych twórców tamtego czasu do 
kształtowania określonych zachowań językowych ogółu społeczeństwa. Artyści wyrażaja w ten sposób troskę o świadome wyzyskiwania słowa, pokazują zindywidualizowane użycie języka, wskazują na możliwość pomnażania operacji językowych na poziomie słowo- i zdaniotwórczym, co w konsekwencji wpływało na rozwój języka narodowego, ${ }^{9}$ który powinien być wolny od szablonu, pustosłowia, efekciarstwa.

Oczywiście, przedstawione wyżej rozważania maja z konieczności charakter wybiórczy, a w związku $z$ tym ukazywanie sposobów eksponowania przez niejęzykoznawców problematyki lingwistycznej nadal pozostaje interesującym polem badań.

\section{Bibliografia}

T. Bocheński, 1936, Język substancja piśmiennictwa, „Kamena. Miesięcznik Literacki" nr 7(27), s. 121-126.

T. Boy-Żeleński, 2001, Znasz li ten kraj?... I inne wspomnienia, Gdańsk.

Z. Dębicki, 1925, Podstawy kultury narodowej, Warszawa.

S. Dubisz, 2012, Język - historia - kultura (wykłady, rozprawy, rozważania), Warszawa.

K. Irzykowski, 1934, Słoń wśród porcelany, Warszawa.

B. Jasieński, 1921a, Mañifest $w$ sprawie poezji futurystycznej, „JEDNODŃUWKA FUTURYSTUW mańifesty futuryzmu polskiego wydańe nadzwyczajne na cała Żeczpospolita Polska", Krakuw [sic!] [https://pl.wikisource.org/wiki/ Jednod\%C5\%84uwka_futurystuw; data dostępu: 20 XII2019].

B. Jasieński, 1921b, „Manifest $w$ sprawie ortografji fonetycznej, JEDNODNUUWKA FUTURYSTUW mańifesty futuryzmu polskiego wydañe nadzwyczajne na cała Żeczpospolita Polska", Krakuw [sic!] [https://pl.wikisource. org/wiki/Jednod\%C5\%84uwka_futurystuw; data dostępu: 20 XII2019].

J. Kurek, 1933, Świadome pisarstwo. Jeszcze elementy i wiazanie, „Linia” nr 5.

K. Makuszyński, 1928, Pieśń o ojczyźnie, Warszawa-Kraków-Lublin-ŁódźParyż-Poznań-Wilno-Zakopane.

T. Peiper, 1925, Nowe usta, Lwów.

T. Peiper, 1974, O wszystkim i jeszcze o czymś. Artykuty, eseje, wywiady (1918-1939), Kraków.

T. Peiper, 1979, Pisma wybrane, oprac. S. Jaworski, Wrocław-Warszawa-Kraków-Gdańsk.

${ }^{9} \mathrm{~W}$ polszczyźnie ogólnej do dziś funkcjonuje wiele „skrzydlatych słów” i sentencji, które wiodą swoje życie w oderwaniu od nazwiska ich twórcy Juliana Tuwima. Wystarczy przypomnieć tylko tytuł programu prowadzonego przez Jana Miodka - Ojczyzna-polszczyzna czy wypowiedzenia takie jak: Odyseusz, król Itaki i owaki; Tu leży ten, co umark; Gdyby jajko miało inna formę, życie kury byłoby potworne; Miłość ci wszystko wybaczy; Błogosławiony ten, co nie majacc nic do powiedzenia, nie obleka tego faktu $w$ słowa; Tak pisać, by słowom było ciasno, a myślom przestronnie; Dura sex, sed sex; Pchła: owad, co zszedł na psy; Gratulacje: najuprzejmiejsza forma zawiści; Rodzynka: stroskane winogrono; Prawo i sprawiedliwość; więcej: Sokólska 2017, 133. 
Poezja polska okresu międzywojennego. Antologia, 1987, t. I i II, wybór i wstęp M. Głowiński, J. Sławiński, Kraków.

J. Przyboś, 1927, Idea rygoru, „Zwrotnica” nr 12.

J. Przyboś, 1984, Utwory poetyckie, t. I, oprac. R. Skręt, Kraków.

J. Przyboś, 1994, Utwory poetyckie, t. II, oprac. R. Skręt, Kraków.

J. Rozwadowski, 1923, Stefan Żeromski. „Snobizm i postęp”, „Język Polski” VIII, s. 87-89.

U. Sokólska, 2013, Niedopowiedzenie i wieloznaczność jako element strategiczny poetyckiej gry językowej w polskiej poezji przełomu wieków, „Poradnik Językowy" z. 5, s. 18-28.

U. Sokólska, 2015, Etymologiczne zabawy Juliana Tuwima, „Poznańskie Studia Polonistyczne”, Seria Językoznawcza, wolumin 22 (42), nr 1, s. 235-252.

U. Sokólska, 2017, „O, mowo polska, ty ziele rodzime”. Wokół refleksji nad kształtem polszczyzny, Białystok.

U. Sokólska, 2018, Polski język poetycki lat 1918-2018-między historia i ideologia a programem poetyckim $i$ środkami artystycznego przekazu, „Poradnik Językowy" z. 8, s. 66-78.

U. Sokólska, 2019, Autotautogram, czyli raz jeszcze $w$ sprawie zabaw Juliana Tuwima brzmieniowa warstwa leksyki, „Studia Językoznawcze”. Synchroniczne i diachroniczne aspekty badań polszczyzny, t. 18, s. 229-239.

S. Żeromski, 1923, Snobizm i postęp [https://literat.ug.edu.pl/snobizm/0003. htm; https://literat.ug.edu.pl/snobizm/0006.htm; https://literat.ug.edu. $\mathrm{pl} /$ snobizm/0009.htm - dostęp: 18 XII 2019].

S. Żeromski, 1963, Pisma literackie i krytyczne, Warszawa.

\section{Language as an object of reflection as approached by the writers of the interwar period}

\section{Summary}

This paper is an attempt at drawing attention to the role played by remarkable authors of the interwar period in creating the national language. It discusses selected statements of artists such as J. Tuwim, T. Boy-Żeleński, J. Przyboś, S. Żeromski, B. Jasieński, J. Kurek, and T. Peiper, for whom language is not only a literary material but also an object of studies and reflection expressed directly, in separate quasi-linguistic texts. This served the purpose of exhibiting the methods of giving consideration to linguistic issues by non-linguists.

Keywords: artistic language - models of Polish in the interwar period - concepts of language development - roles of the general language in the society 